\title{
Use of Ventilator Care Bundle to Prevent Ventilator-Associated Pneumonia: The Impact of Using Echinacea as a Complementary Modality
}

\author{
JEHAN A. EL-KHOLY, M.D.*; IMAN A. FOUAD, M.D.*; AKRAM S. EL-ADAWY, M.D.*; \\ HEBA F. SHAFEI, M.D.** and MONA S. ALLAM, M.Sc.* \\ The Department of Anesthesiology, Intensive Care and Pain Management, Faculty of Medicine, Cairo University* and \\ The Department of Complementary and Alternative Medicine, National Research Centre, Giza**, Egypt
}

\begin{abstract}
Background: Ventilator Associated Pneumonia (VAP) is one of the most common hospital acquired infections in Intensive Care Unit. It is a complication in many patients who receive mechanical ventilation. One of the recent approaches for prevention of VAP was the application of ventilator care bundle which includes; head of bed elevation, deep vein thrombosis prophylaxis, peptic ulcer disease prophylaxis, daily sedation vacation, daily assessment for readiness for extubation, daily spontaneous breathing trial, and oral care with chlorohexadine. Echinacea is a herb that has been utilized to strengthen the body's innate resistance. It contains multiple active compounds which gives it its medicinal qualities, it has been shown to reduce the severity of respiratory infections. This herb may be used in prophylaxis against VAP.
\end{abstract}

Aim of Study: The objective of this study was to evaluate the effect of adding Echinacea to ventilator care bundle in intubated and ventilated ICU patient on prophylaxis against ventilator associated pneumonia.

Material and Methods: This clinical trial included 80 patients who were intubated and mechanically ventilated within 48 hours of admission to ICU in Surgical Intensive Care Unit (SICU) in Kasr Aini Hospital during the period between December 2013 and December 2014. All patients were adults more than 18 years, who have no witnessed aspiration or pneumonia on admission.

Intervention: Patients were divided into two equal groups of 40 patients each, one group received Echinacea in the form of Immulant capsules and the other didn't receive it. Both groups have ventilator care bundle applied. All patients were followed-up clinically, radiologically and by laboratory assessment. VAP was suggested according to Clinical Pulmonary Infection Score (CPIS).

Results: Inflammatory indicators in the form of occurrence of fever and rising trend in the count of WBCs in the first

Correspondence to: Dr. Jehan A. El-Kholy, The Department of Anesthesiology, Intensive Care and Pain Management, Faculty of Medicine, Cairo University five days were significantly less in the group that received Echinace. Gram negative organisms were the most prevalent in cases with VAP with no statistical difference between both groups in the type of organisms. VAP rate had no significant difference between the two groups.

Conclusion: No apparent difference is found on adding Echinacea to ventilator care bundle on prevention of VAP, But Echinacea may be found to decrease severity of inflammatory reactions reducing VAP complications.

Key Words: Echinacea-Ventilator care bundle - Ventilator associated pneumonia - Intensive Care UnitMechanical ventilation.

\section{Introduction}

VENTILATOR Associated Pneumonia (VAP) is defined as pneumonia occurring more than 48 hours after patients have been intubated and received mechanical ventilation [1]. It is a common concern in critical care department, where its incidence can run as high as 65\% [2]. Several risk factors have been reported to be associated with VAP, including the duration of mechanical ventilation, the presence of chronic pulmonary disease, sepsis, Acute Respiratory Distress Syndrome (ARDS), neurological disease, trauma, prior use of antibiotics, and red cell transfusions [3]. VAP can increase a patient's length of stay by 4.3 days with increase total cost of care and possibly high mortality rates [4]. The occurrence of VAP has become one of the quality indicators in many health care systems. Several interventions have been found to reduce the incidence of VAP, including head of bed elevation, deep vein thrombosis prophylaxis, peptic ulcer disease prophylaxis, daily sedation vacations, daily assessment for readiness to extubate, daily spontaneous breathing trial and oral care with chlorohexidine. These clinical interventions are called ventilator care bundle [5] 
Echinacea has been utilized for its medicinal properties for over 400 years by Native Americans to treat infections and general illnesses. This herb contains multiple active compounds, which includes volatile oils, alkamides, glycoproteins, flavonoids and polysaccharides. The combinations of these chemicals give Echinacea its medicinal qualities. Echinacea strengthens the body's innate resistance and, if indeed the hyaluronidase enzyme inhibiting action is a factor, inhibits the proliferation of bacteria by increasing phagocytic activity [6].

The National Center for Complementary and Alternative Medicine in the United States of America states that Echinacea has been shown as an effective way to treat and reduce the severity of respiratory infections [7].

In Egypt, Echinacea is a component of some drugs like; Immulant $175 \mathrm{mg}$ capsules, and Immulone lozenge (Echinacea 150mg + vitamin C 50mg). It is believed to activate monocytes macrophage cell function, increase leukocyte mobilization towards site of infection, and rise lysosomal enzyme activity of macrophages [8]

The aim of this study is to establish the effect of implementation of ventilator care bundle combined with Echinacea on VAP rate in mechanically ventilated patients.

\section{Patients and Methods}

A randomized controlled study was conducted in Surgical Intensive Care Unit (SICU) in Kasr Aini Hospital, where patients were admitted from general surgery and trauma units to receive mechanical ventilation.

The study included 80 patients, presented to SICU during the period between December 2013 and December 2014 constituted the study population. All patients were adults, more than 18 years old and intubated within 48 hours of admission to ICU. Patients who are drug induced immunocompromized, had pneumonia, had witnessed aspiration, had hypersensitivity to Echinacea, or pregnant females are excluded.

All patients had ventilator care bundle applied and patients were divided into two groups: Group A; had Echinacea in the form of (Immulant capsules $350 \mathrm{mg}$ three times daily for 5 days), and Group B; didn't receive Echinacea.

Ventilator care bundle consisted of 6 components: Head of bed elevation greater than 30 degree, daily sedation break by attempting daily dose reduction of continuous sedatives and by adjusting sedation to target ventilator adjusted motor assessment scoring scale, daily assessment for readiness for weaning, peptic ulcer prophylaxis by proton pump inhibitors (controloc 40mg) once daily or $\mathrm{H} 2$ antagonists, deep venous thrombosis prophylaxis by low molecular weight heparin unless contraindicated $(0.5 \mathrm{mg}$ per $\mathrm{Kg}$ once daily and dose is adjusted in renal patients), and topical buccal $1 \%$ chlorhexadine gel twice daily.

Compliance to ventilator care bundle was assessed daily by an independent observer. Compliance was recorded as yes or no for each bundle item. The entire bundle was considered compliant only if all 6 items were compliant. A bundle was considered noncompliant if any item was not performed, unless it is contraindicated.

\section{All patients were subjected to the following:}

Full history taking with special emphasis was made on cause of SICU admission, medications received, history of prior admission(s) to health care facility or ICU, and previous chest infection, and ongoing medications. Risk factors predisposing to chest infection were also particularly considered including; smoking, COPD, DM, old age, invasive chest trauma, immunocompromized patients, and major surgical interventions.

Through clinical examination with special emphasis on; chest condition and signs of pneumonia and COPD, signs of debility, hemodynamic status of the patient, body temperature, signs of complications of mechanical ventilation, and readiness for extubation.

Laboratory investigations with special emphasis on admission and follow-up WBCs level, and sputum or trans bronchial aspirate culture and sensitivity if available.

Imagings with special emphasis on plain chest $\mathrm{X}$-ray on admission and as required.

VAP rate was defined as the number of VAP cases per 1000 ventilator day. A ventilator day was defined as a calendar day for which the patient is charged for mechanical ventilation. VAP rate was calculated as VAP patients* 1000/ventilator days. Cases of VAP were identified by the attending intensivists during routine daily round using Clinical Pulmonary Infection Score (CPIS) [9] . A score of more than 6 is considered suggestive of pneumonia. The results were tabulated and statistically analyzed. 
Table (1): Shows CPIS criteria and scoring.

\begin{tabular}{|c|c|c|}
\hline Item & Criteria & Score \\
\hline - Temperature & $\begin{array}{l}\bullet \geq 36.5 \text { and } \leq 38.4 \\
\bullet \geq 38.5 \text { and } \leq 38.9 \\
\bullet \geq 39 \text { and } \leq 36\end{array}$ & $\begin{array}{l}0 \\
1 \\
2\end{array}$ \\
\hline - Blood leucocytes, & $\begin{array}{l}\cdot \geq 4.000 \text { and } \leq 11.000 \\
\cdot<4.000 \text { or }>11.000 \\
\cdot<4.000 \text { or }>11.000 \\
\cdot \text { +band forms } \geq 50 \%\end{array}$ & $\begin{array}{l}0 \\
1\end{array}$ \\
\hline - Tracheal secretions & $\begin{array}{l}\text { - Absence of tracheal secretions } \\
\text { - Presence of non purulent } \\
\text { secretions } \\
\text { - Presence of purulent secretions }\end{array}$ & $\begin{array}{l}0 \\
1 \\
2\end{array}$ \\
\hline $\begin{array}{l}- \text { Oxygenation }\left(\mathrm{PaO}_{2} /\right. \\
\left.\mathrm{FiO}_{2}\right), \mathrm{mmHg}\end{array}$ & $\begin{array}{l}\cdot>240 \text { or ARDS } \\
\cdot \leq 240 \text { and no ARDS }\end{array}$ & $\begin{array}{l}0 \\
2\end{array}$ \\
\hline $\begin{array}{l}\text { - Pulmonary } \\
\text { radiology }\end{array}$ & $\begin{array}{l}\text { - No infiltrate } \\
\text { - Diffuse or Patchy infiltrate } \\
\text { - Localized infiltrate }\end{array}$ & $\begin{array}{l}0 \\
1 \\
2\end{array}$ \\
\hline $\begin{array}{l}\text { - Progression of } \\
\text { pulmonary infiltrate }\end{array}$ & $\begin{array}{l}\text { - No radiographic progression } \\
\text { - Radiographic progression } \\
\text { (after CHF \& ARDS excluded) }\end{array}$ & $\begin{array}{l}0 \\
2\end{array}$ \\
\hline $\begin{array}{l}\text { - Culture of tracheal } \\
\text { aspirate }\end{array}$ & $\begin{array}{l}\text { - Negative } \\
\text { - Positive }\end{array}$ & $\begin{array}{l}0 \\
2\end{array}$ \\
\hline
\end{tabular}

ARDS is defined as $\mathrm{PaO}_{2} / \mathrm{FiO}_{2} \leq 200$, Pulmonary artery wedge pressure $\leq 18 \mathrm{mmHg}$, and acute pulmonary infiltrate.

\section{Statistical analysis:}

All data were collected, tabulated, and statistically analyzed. The descriptive statistics in the form of mean and standard deviation for quantitative data and frequency for qualitative data. The analytical statistics included paired sample $(t)$ test, Chi square test for qualitative data analysis, and $p$-value to denotes the level of significance. All statistical calculations were done using computer program SPSS (Statistical Package for Social Science [10]

\section{Results}

The purpose of this study was to examine the effect of adding Echinacea as an immune stimulant to the ventilator care bundle measures in the prevention of VAP. At the start of the study ninetysix patients were included, nine patients of them were excluded because of receiving corticosteroids, four patients were excluded because of witnessed aspiration, and three patients were excluded because they didn't complete 48 hours on mechanical ventilation. 80 patients (64 males and 16 females), with age ranged from 19 to 79 years with mean age 49 years, were intubated and connected to mechanical ventilator within 48 hours of admission to the ICU constituted the population of this study.

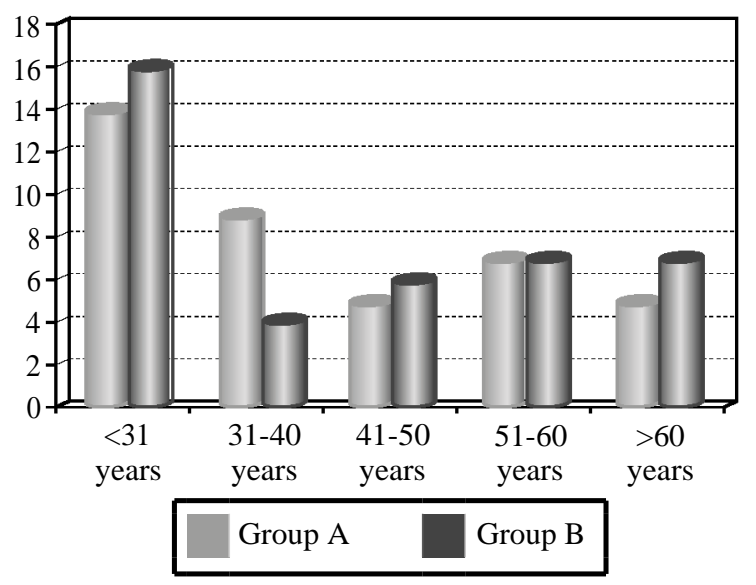

Graph (1): Show age characteristics of study population.

Patients were divided into 2 equal groups of 40 patients each, the first group (Group A) that included 40 patients (30 males and 10 females), had Immulant capsules $350 \mathrm{mg}$ three times daily for five days beside ventilator care bundle measures, and the second group (Group B) that included 40 patients (34 males and 6 females) had ventilator care bundles measures only.

Primary outcomes measuring VAP rates were diagnosed by clinical picture, white blood cell count, basal and follow-up chest X-ray, and secondary outcomes measuring duration of ICU stay and VAP associated mortality as VAP complications were evaluated.

On admission there was no statistical difference between both groups regarding WBC count that had a mean of $16 \pm 7 * 1000$ cell in Group A, and a mean of $17 \pm 8 * 1000$ cell in Group B as shown in (Table 2).

Table (2): Admission mean WBC count in both groups.

\begin{tabular}{lccc}
\hline & Group A & Group B & $p$-value \\
\hline $\begin{array}{l}\text { - Mean WBCs on } \\
\text { admission }\end{array}$ & $16 \pm 7$ X 1000 & $17 \pm 8$ X 1000 & 0.563 \\
\hline
\end{tabular}

During the study WBC count had a rising trend (during the first 5 days of ICU admission in 49 patients in Group A, and 30 patients in Group B with a statistically significance between the 2 groups $(p$-value $=0.0177)$ as shown in $($ Table 3$)$.

Table (3): Trend of WBC count in both groups.

\begin{tabular}{lccc}
\hline & $\begin{array}{c}\text { Group A } \\
\text { Number of } \\
\text { patients } \\
\text { (percentage) }\end{array}$ & $\begin{array}{c}\text { Group B } \\
\text { Number of } \\
\text { patients } \\
\text { (percentage) }\end{array}$ & $p$-value \\
\hline - Number of patients \\
$\begin{array}{l}\text { with rising trend of } \\
\text { WBCs }\end{array}$ & $19(47.5 \%)$ & $30(75 \%)$ & $0.0177^{*}$ \\
*: Means significant. & & & \\
\hline
\end{tabular}


Fever (started after 48 hours of intubation, more the $38.9^{\circ} \mathrm{C}$ and lasts more than 24 hours) was present in 44 patients; 17 patients in Group A and 27 patients in Group B and the difference between the 2 groups was statistically significant ( $p$-value $=0.025)$. As shown in (Table 4).

Prolonged intubation i.e more than 7 days was found in 21 patients in Group A and 26 patients in Group B with no statistical significance between both groups $(p$-value $=0.256)$ as shown in $($ Table 4$)$.

Total mortality was 40 patients: 21 patients from Group A and 19 patients from Group B. It was statistically not significant $(p$-value $=0.655)$ as shown in (Table 4) and Graph (2).

Table (4): Patient progression in both groups.

\begin{tabular}{lccl}
\hline & $\begin{array}{c}\text { Group A } \\
\text { Number of } \\
\text { patients } \\
\text { (percentage) }\end{array}$ & $\begin{array}{c}\text { Group B } \\
\text { Number of } \\
\text { patients } \\
\text { (percentage) }\end{array}$ & $p$-value \\
\hline - Fever & $17(42.5 \%)$ & $27(67.5 \%)$ & $0.025^{*}$ \\
- Patients with DOI & $21(52.5 \%)$ & $26(65 \%)$ & 0.256 \\
$\begin{array}{l}>7 \text { days } \\
\text { - Mortality }\end{array}$ & $21(52.5 \%)$ & $19(47.5 \%)$ & 0.502 \\
\hline
\end{tabular}

*: Means significant.

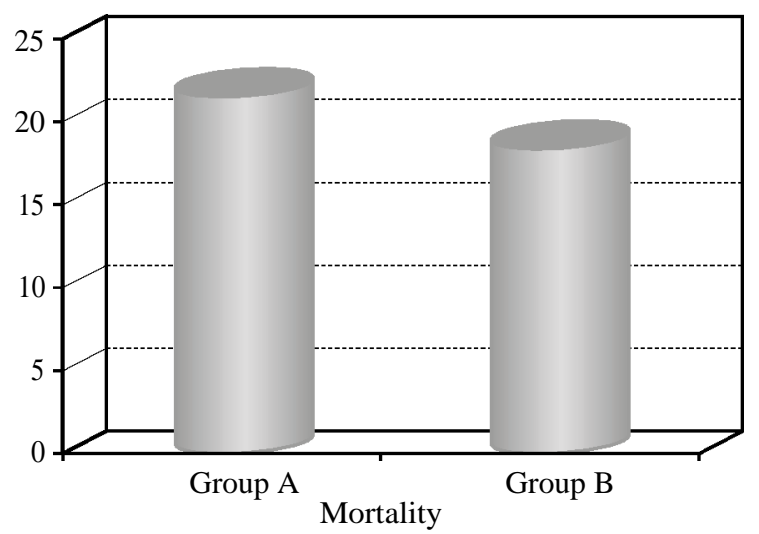

Graph (2): Mortality in both groups.

VAP rate is 3.9/1000 ventilator dayin Group A, and 5.3/1000 ventilator day in Group B, it was statistically not significant ( $p$-value $=0.08)$ as shown in (Table 5).

Total number of patients acquired VAP were 33 patients, fourteen patients in Group A, and nineteen patients in Group B ( $p$-value $=0.256)$ as shown in (Table 5) and Graph (3).

Gram negative organisms were the most prevalent, followed by gram positive organisms. Isolated organisms are; Acinetobacter, Klebsiella, Pseudomonas, E.coli, CoNS, S.aureus.
Table (5): VAP characteristics in both groups.

\begin{tabular}{llll}
\hline & \multicolumn{1}{c}{ Group A } & \multicolumn{1}{c}{ Group B } & $p$-value \\
\hline - VAP rate & $3.9 / 1000 \mathrm{v}$. day & $5.3 / 1000 \mathrm{v}$. day & 0.08 \\
- Patients with & $14(35 \%)$ & $19(47.5 \%)$ & 0.256 \\
$\begin{array}{l}\text { VAP (number } \\
\text { of patients }\end{array}$ & & & \\
(percentage) & & & \\
\hline
\end{tabular}

*: Means significant.

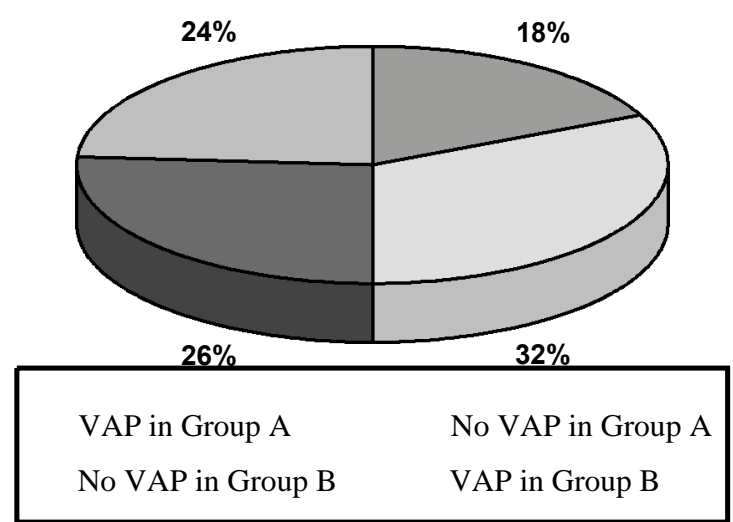

Graph (3): VAP incidence in both groups.

\section{Discussion}

Previous studies had demonstrated a positive impact in reducing VAP on patient outcome through the implementation of Ventilator Care Bundle (VCB) that included the Center of Disease Prevention and Control (CDC) components [11] . Components of the bundle are used to prevent ventilator associated pneumonia, they may be ineffective against pneumonia when used separately but when grouped together, they decrease numbers of VAP in ICU [12].

In our study, we examined the effect of Echinacea purpura (immulant capsules) on VAP prevention when added to VCB.

Echinacea purpura is believed to be an immunestimulator, stimulating the body's non-specific immune system and warding off infections, [13] that is used in prevention and treatment of Upper Respiratory Tract Infections (URTI). The European Medicines Agency (EMA) approved the use of expressed juice and dried expressed juice from fresh flowering aerial parts of Echinacea purpura for the short-term prevention and treatment of the common cold and upper respiratory tract infections [14]. A review from the University of Maryland on 13 European studies concluded that echinacea, when taken at first sign of cold, reduced cold symptoms or shortened their duration [14] 
To our knowledge, this is the first research to study the role of Echinacea on Lower Respiratory Tract Infections (LRTI).

Despite the number of men is more than the number of women in the study, however, no significant difference regarding both mortality and prolonged stay between the genders was identified. Most of the studies confirmed these data [15]. On the contrary, Fowler et al., [16] found a higher mortality rate in women.

The fundamental results of our study were: The incidence of VAP was $41.25 \%$, (35\% in Group A, and $47.5 \%$ in Group B). With a VAP rate of 3.9/ 1000 ventilator day in Group A, and 5.3/1000 ventilator day in Group B, with no significant changes between the two groups.

In a study by Mi Suk et al., studying the epidemiology of VAP and collecting data from 31 nonteaching community hospitals throughout Virginia, North Carolina, South Carolina, and Georgia showed the median incidence of VAP was 1.4/1000 ventilator-days, [17] while most hospitals experienced an average of only 1/1000 VAP per year [18] In public (government led) hospitals in Malaysia, the incidence of VAP was 7.2 per 1000 ventilator days in 2012 [19]. Bird et al., found an incidence of 10.2 VAP cases/1000 ventilator days has been reported in some trauma ICUs [20]. Bird et al., found that approximately 8 to 28 percent of critical care patients intubated during their stay in ICU will develop a VAP [20]. Some studies have reported a varied incidence from 17-30\%, depending upon the diagnostic criteria used in diagnosing VAP [21] The reported incidence of VAP is higher in academic institutions [22].

Whether VAP is $100 \%$ preventable is controversial. Some hospitals have reported VAP rates at or close to 0 using prevention bundles [23]. Other experts have argued that VAP cannot be eliminated because they have had persistent VAP cases despite aggressive use of prevention bundles [24]. Blot et al argue that it is unrealistic to suggest that VAP can be eliminated in the most complex ventilated populations [25]

In our study gram negative organisms were the most prevalent, followed by gram positive organisms. Isolated organisms are; Acinetobaacter, Klebsiella, Pseudomonas, E.coli, CoNS, S.aureus, Candida, and others.

In a study done in the Medical Intensive Care Unit of Kasr El-Aini Hospital, Cairo University, it was found that that initial causative organisms were: Klebsiella, followed by Acinetobacter, Pseudomonas, Multiple growth (Klebsiella \& Pseudomonas), multiple growth (Klebsiella \& Acinetobacter), E.Coli, Citrobacter and Proteus [26]

In a study by Turković TM et al., it was found that; the most commonly isolated bacterium was Staphylococcus aureus (21.1\%), followed by Pseudomonas aeruginosa (19.0\%) and Acinetobacter species (13.6\%) [27]

In another study by Mohanty et al., it was found that; the most common organism isolated was $P$. aeruginosa, the next most common organism isolated was MRSA. Other common organisms isolated were K. Pneumoniae and A. baumannii [28]

In a study by Jakribettu et al., Klebsiellapneumoniae (36\%) was the most common isolate followed by Pseudomonas aeruginosa $(21 \%)$ and Acinetobacterspecies (15\%) [29].

There was no statistical difference in WBCs count on admission between the 2 groups, this observation helped us in studying the trend of WBC count change in both groups.

On studying the WBCs increasing trend within the first 5 days of admission, we found that it was more significant in Group B than in Group A. Also, fever occurrence was more significant in Group B. Both previous observations suggested that Echinacea helped in decreasing severity of inflammatory reaction to invading organism, and supported early improvement.

A study performed by Paul Bergner, 2011 found that, during administration of Echinacea in normal individuals, the daily white blood counts showed normal individual variations within the group. In every case there was a marked leukocyte increase during the first two days. In two-thirds of the cases the highest count occured at the end of twentyfour hours' medication. In the remaining third, the peak was reached after forty-eight hours' administration. From the highest point, the counts of the white cells (total) gradually dropped and approximated the normal count during the third and fourth days [13]

It is known that WBCs returns to normal value by the fifth day after subsidence of infection in $90 \%$ of cases. Persistance of increasing WBCs suggesting persistence of infection [30]

Echinacea (Echinacea purpurea, Echinacea pallida) is a common fever reducing herb that is used for acute infections with fever. Echinacea has natural properties like antiviral, antimicrobial and 
immune system stimulant which may ultimately reduce fever, inflammation and pain [31].

\section{Conclusion:}

No apparent difference is found on adding Echinacea to VCB on prevention of VAP, but, Echinacea may decrease the severity of inflammatory reactions promoting faster improvement and reduction in VAP complications in affected individuals. More studies are required to support this hypothesis.

\section{Recommendation:}

Independent studies on the effect of Echinacea on Lower Respiratory Tract infections with a larger group of population are required to confirm our results and to provide more scientific knowledge about this herb.

If confirmed in independent studies, our finding that Echinace is a strong immunostimulator, may have important clinical applications.

\section{Study limitations:}

Our results were obtained in selected surgical ICU patients; they may not apply to all ICU patients.

Bias in diagnosis of VAP in ICU still present as the clinical diagnosis of VAP is neither sensitive nor specific [32].

Limited sample size is a limitation factors that may have affected the present study, and hence could not deduce statistical significance of the findings.

\section{Declaration of patient consent:}

All appropriate patient consent forms were obtained, patients gave their consent for their clinical information to be reported and understand that their names and initials will not be published.

Financial support and sponsorship:

Nil.

\section{Conflict of interest:}

There are no conflicts of interest.

\section{References}

1- STEVEN M. KOENIG and JONATHON D. TRUWIT: Ventilator-Associated Pneumonia: Diagnosis, Treatment, and Prevention. Clinical Microbiology Reviews. American Society for Microbiology, 19 (4): 637-57, 2006.

2- DODEK P., KEENAN S., COOK D. and HEYLAND D.: "Evidence-Based Clinical Practice Guidelines for the Prevention of Ventilator-Associated Pneumonia [clinical guidelines]" Annals of Internal Medicine, 141 (4): $305-$ 13, 2004.

3- TEJERINA E., FRUTOS-VIVAR F., RESTREPO M.I., ANZUETO A., ABROUG F., PALIZAS F., GONZÁLEZ M., D'EMPAIRE G., APEZTEGUÍA C. and ESTEBAN A.: Incidence, risk factors, and outcome of ventilatorassociated pneumonia. J. Crit. Care, 21: 56-65, 2006.

4- KOLEFF M.: Prevention of Hospital-Associated Pneumonia and Ventilator-Associated Pneumonia" Critical Care Medicine, 32 (6): 1,396-1,405, 2004.

5- CHLEBICKI M.P. and SAFDAR N.: Topical chlorhexidine for prevention of ventilator-associated pneumonia: A meta-analysis. Crit. Care Med., 35 (2): 595-602, 2007.

6- MICHAEL TIERRA R.H.: Treating Staph Infections Including MRSA with Echinacea. East West School of Planetary Herbology. http://www.planetherbs.com/ therap ie s/tre ating-staph-infe ctions-including-mrsa-withechinacea.html, 2012.

7- JONATHAN McLELLAND: Herbal Remedy for Bacterial Chest Infection, Jun. 14, 2011, Article reviewed by Christine Brncik Last updated on: Jun. 14, 2011.

8- Dr. HENEIN WELY and Dr. USAMA THARWAT: Drug Index, Master on Therapeutic drugs, 2003.9-JPugin. Clinical signs and scores for the diagnosis of ventilator associated pneumonia. Minerva Anestesiol. 68(4):261-5, 2002.

10- SPSS Inc., Chicago, IL, USA) release 15 for Microsoft Windows. 2006.

11- MUSCEDERE J., et al.: Comprehensive evidence-based clinical practice guidelines for ventilator associated pneumonia: Prevention. J. Crit. Care, 23: 126-37, 2008.

12- SCOTT M. and KEENE S.: What is the role of the allied health professional in preventing ventilator acquired pneumonia? Int. J. Infec. Diseases, 7 (1), 2009.

13- PAUL BERGNER, ECHINACEA: Eclectic Research, Its effect on the normal individual; with special reference to changes produced in the blood picture, 07-31-94 6 (2): 4-5 medical herbalism, Journal for medical practiotionar, 2001.

14- PAUL BERGNER: "Healing Power of Echinacea and Goldenseal and Other Immune System Herbs" (The Healing Power), prima publishing Feb. 1997. www.books. google.com.eg/books.

15- New Study on Echinacea is Faulty, says Canadian-Based Company Medical News Today, August 15, 2005.

16- FOWLER R.A., SABUR N., LI P., JUURLINK D.N., PINTO R., HLADUNEWICH M.A., et al.: Sex-and agebased differences in the delivery and outcomes of critical care. CMAJ, 177 (12): 1513-9, 2007.

17- LEE, VANESSA WALKER, LUKE F. CHEN, DANIEL J. SEXTON, and DEVERICK J. ANDERSON: The Epidemiology of Ventilator-Associated Pneumonia in a Network of Community Hospitals: A Prospective Multicenter Study Infect Control Hosp. Epidemiol., Jul., 34 (7): $657-$ 62, 2013.

18- SUNDAR K.M., NIELSEN D. and SPERRy P.: Comparison of ventilator-associated pneumonia (VAP) rates between different ICUs: Implications of a zero VAP rate. J. Crit. Care, 27: 26-32, 2012. 
19- TONG J., GEOK M., LING T.L., CHENG T., OTHMAN A.S., ABDUL A.N., SHUKOR A. and HAR L.C.: Malaysian Registry of Intensive Care. The 2012 Report. Available at: http://www.mric.org.my/Content/Document/ MRICPublications/mricreport_pdf [accessed 07/08/2014], 2012.

20- BIRD D., ZAMBUTO A., O'DONNEL C., SILVA J., KORN C., BURKE R., BURKE P. and AGARWAL S.: Adherence to ventilator-associated pneumonia bundle and incidence of ventilator-associated pneumonia in the surgical Intensive Care Unit. Archives Surgery, 145 (5): 465-70, 2010.

21- IBRAHIM E.H., TRACY L., HILL C., FRASER V.J. and KOLLEF M.H.: The occurrence of ventilator-associated pneumonia in a community hospital: Risk factors and clinical outcomes. Chest Aug., 120 (2): 555-61, 10.1378/ chest. 120.2.555, 2001.

22- AKÇA O., KOLTKA K., UZEL S., CAKAR N., PEMBECI K., SAYAN M.A., et al.: Risk factors for early-onset, ventilator-associated pneumonia in critical care patients: Selected multiresistant versus nonresistant bacteria. Anesthesiology Sep., 93 (3): 638-45, 2000.

23- SUNDAR K.M., NIELSEN D. and SPERRY P.: Comparison of ventilator-associated pneumonia (VAP) rates between different ICUs: Implications of a zero VAP rate. J. Crit. Care, 27: 26-32, 2012.

24- BOUADMA L., DESLANDES E., LOLOM I., et al.: Long-term impact of a multifaceted prevention program on ventilator-associated pneumonia in a medical intensive care unit. Clin. Infect. Dis., 51: 1115-22, 2010.

25- BLOT S., LISBOA T., ANGLES R. and RELLO J.:
Prevention of VAP: Is zero rate possible? Clin. Chest. Med., 32: 591-9, 2011.

26- AMAL ELSHIMY, RANIA SHASH and AYMAN SEDDIK: Effectiveness of Adjunctive Inhaled Colistin in Treatment of Ventilator Associated Pneumonia, Egyptian Journal of Medical Microbiology, Vol. 24, No. 1 23, 2015.

27- TURKOVIC' GASPAR B., SIRANOVIC' M. and PERIC' M.: Microbial profile and antibiotic susceptibitlity patterns of pathogens causing ventilator-associated pneumonia at intensive care unit, Sestremilosrdnice University Hospital Center, Zagreb, Croatia. Acta Clin. Croat., 54 (2): 127-35, 2015.

28- MOHANTY, SIDHARTH SRABAN ROUTRAY, DEBASIS MISHRA and ABHILAS DAS: Ventilator Associated Pneumonia in a ICU of a Tertiary Care Hospital in India Debaprasad, International Journal of Contemporary Medical Research Volume 3, Issue 4, 2016.

29- RAMAKRISHNA PAI JAKRIBETTU, REKHA BOLOOR and SUCHARITHA SURESH: Comparison of microbiological profile of pathogens isolated from early-onset and late-onset ventilator-associated pneumonia in a tertiary care center. Volume 19, Issue 1, Page: 14-9, 2016.

30- ANTONIO M. ESQUINAS: Applied Technologies in Pulmonary Medicine, http://www.karger.com/Article/PDF, 2011.

31- PAULINA NELEGA: Fever reducing herbs, natural wellbeing, http://corp.naturalwellbeing.com/learningcenter. 2015.

32- KLOMPAS M.: Ventilator-associated events surveillance: A patient safety opportunity. Curr. Opin. Crit. Care, 19: 424-31, 2013 


\section{إستخلام سلسلة الرعاية بجهاز التنفس الصناعى فى الوقاية من حدوث إلتهاب رئوى:

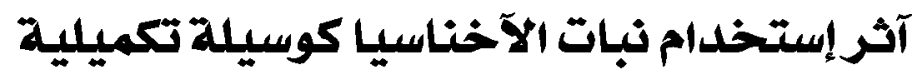

يعتبر مرض الإلتهاب الرئوى المصاحب لإستخدام جهاز التفس المناعى واحداً من آكثر عدوى المستشفيات إنتشاراً فى الرعايات المركزة،

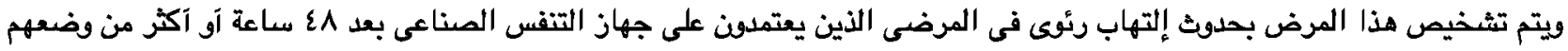

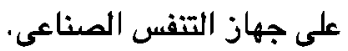

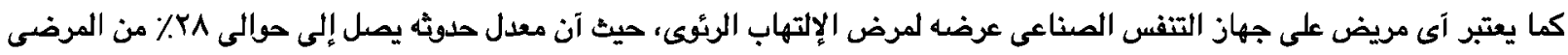

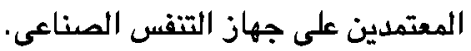

تم فى هذه الدراسة بحث إضافة نبات الإخناسيا لحزمة العناية بالتنفس الصناعى فى التآثير على الوقاية من الإلتهاب الرئوى فى هؤلاء التهاء

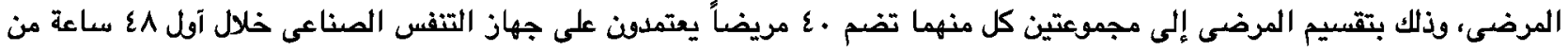

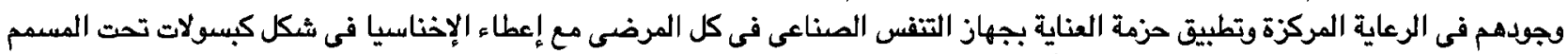

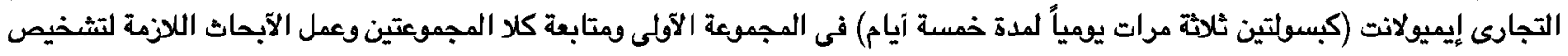
حلوث إلتهاب رئوىى.

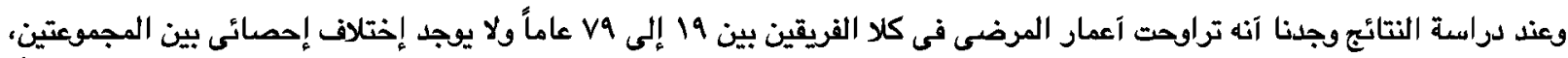

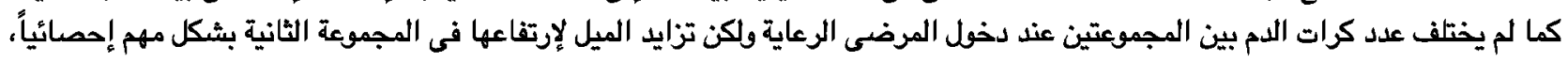
وكذلك إرتفاع لدرجة الحرارة في المجموعة الثانية.

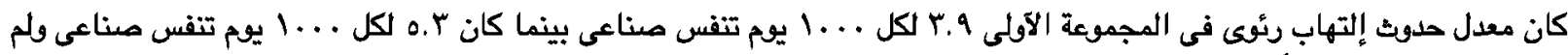

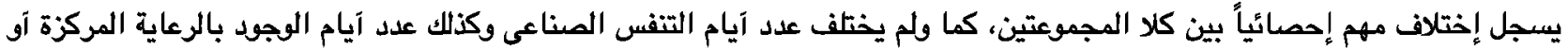
معل الوفيات بين كالا المجموعتين بشكل مهم إحصائياً.

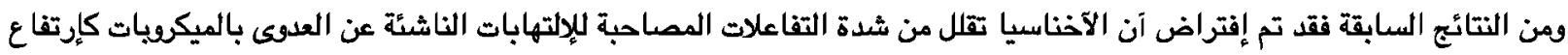

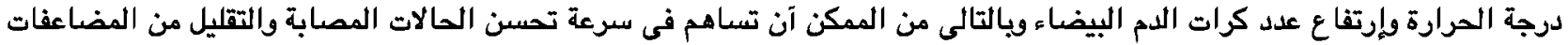
النجة عن ذلك. 